\title{
Challenges of Occupational Safety Specialists' Scale: A Scale Development Study
}

\author{
Şeyhmus AKSOY ${ }^{1}$, Nihal MAMATOĞLU²
}

\begin{abstract}
The object of this study was to develop challenges of occupational safety specialists scale for Turkish sample. The universe of this research is occupational safety specialists who works in private sector. Scale consist of two parts that were the main challenges and organizational challenges part. 332 participants responded main challenges part and 314 participants responded organizational challenges part. The results of the Exploratory Factor Analysis ( EFA) and Confirmatory Factor Analysis (CFA) showed that organizational challenges part have to be assessed as a separate scale from main challenges part. 6 factor was obtained for main challenges with 28 items which were named as 'insufficient awareness of employees' (13 items), 'providing lack of resources' (3 items), 'ignorance of employees' (3 items), 'unwillingness of employees to participation' (3 items), 'legislative challenges'( 3 items) and 'law based challenges' (3 items). Additionally, 1 factor was obtained for organizational challenges part with 6 items. As a result, psychometrics specifics of both main challenges scale and organizational challenges scale showed that scales were valid and reliable for Turkish sample.
\end{abstract}

Keywords: challenges, organizational challenges, occupational safety specialist, scale development

\section{İş Güvenliği Uzmanlarının Sorunları Öıçeği: Bir Ölçek Geliştirme Çalışması}

\begin{abstract}
Özet: $\mathrm{Bu}$ çalışmanın amacı Türk örnekleminde bağlamında kullanılmak üzere iş güvenliği uzmanlarının sorunları ölçeği geliştirilmesidir. Bu araştırmanın evreni özel sektörde çalışan iş güvenliği uzmanlarıdır. Ölçek ana sorunlar ve organizasyonel sorunlar olmak üzere 2 bölümden oluşmaktadır. Ana sorunlar bölümü 332, organizasyonel sorunlar bölümü ise 314 katılımcı tarafindan yanıtlanmıştır. Açımlayıcı Faktör Analizi (AFA) ve Doğrulayıcı Faktör Analizi (DFA) sonuçları organizasyonel sorunların ana sorunlardan ayrı bir ölçek olarak değerlendirilmesi gerektiğini göstermiştir. Ana sorunlar ölçeği 'işverenin yetersiz farkındalı̆̆ı' (13 madde), 'yetersiz kaynak sağlanması' (3 madde), 'çalışanların önemsememesi' (3 madde), 'çalışanların katılım isteksizliği' (3 madde), 'mevzuattan kaynaklanan sorunlar' (3 madde) ve yasadan kaynaklanan sorunlar' (3 madde) olarak adlandırılan 6 faktörlü 28 soruluk bir yapı oluşturmuştur. Öte yandan, organizasyonel sorunlar için 1 (bir) faktörlü 6 soruluk bir yapı ortaya çıkmıştır. Sonuç olarak, ana sorunlar ve organizasyonel sorunlar ölçeklerinin psikometrik özellikleri göstermiştir ki, bu 2 ölçek Türk örnekleminde kullanılabilecek geçerli ve güvenilir ölçeklerdir.
\end{abstract}

Anahtar Kelimeler: sorunlar, organizasyonel sorunlar, iş güvenliği uzmanı, ölçek geliştirme

\footnotetext{
${ }^{1}$ Şeyhmus Aksoy, Sakarya University, Occupational Health and Safety Coordinatorship, e-mail: seyhmus.aksoy1@ @mail.com

${ }^{2}$ Pof. Dr. Nihal Mamatoğlu, Bolu Abant İzzet Baysal University, Faculty of Science and Letters, Psychology Departmant, e-mail: mamatoglunihal@yohoo.com
}

Address of correspondence/ Yazışma adresi: Şeyhmus Aksoy, Sakarya University, Sakarya-Turkey, E-mail: seyhmusaksoy@sakarya.edu.tr Date of received/ Geliş Tarihi: 08.07.2019, Date of acceptance/ Kabul Tarihi: 26.07.2019

Citing/ Referans Gösterimi: Aksoy, Ş. \& Mamatoğlu, N., (2019). Challenges of Occupational Safety Specialists' Scale: A Scale Development Study. Cyprus Turkish Journal of Psychiatry \& Psychology, 1(2): 76-84 doi:10.35365/ctjpp.19.1.09 


\section{Introduction}

In this study, researchers was aimed to develop psychometrically reliable and valid challenges of occupational safety specialists' scale for Turkish sample. Original form of scales are Turkish as could be seen in the Appendix.

In Europe, there has been considerable improvements in the area of occupational health and safety professions in the last 40 years (Atherley \& Hale, 1975; Hale, Piney \& Alesbury, 1986; Cattaruzza \& Huguet, 1993). Requirements for employers to have professional recommendation on health and safety problems has been established at legislation level (European Commission, 1989). Safety professionals have crucial role in ensuring health and safety of workplaces. They generally have task of performing risk assessments, health and safety audits, develop safety prevention and reports of safety incidents (Leitão, Mc Carthy \& Greiner, 2018). Safety professionals are also considered as problem solver in the organizations. They are entailed to solve wide range of health and safety issues by identifying risks and hazards and proposing solutions (INSHPO, 2017).

After 6331 no. OHS Law was enacted, Turkish occupational health and safety system has entered into rapid change with attributing parties' responsibilities, obligations and authorities. Although there are many positive ideas on OHS legislation of Turkey, some parties including judges consider OHS legislation as complex and detailed. Employers' complaint about rapid changes in OHS legislation, to be expected to apply legislation in short time. All parties agree with that present OHS legislation couldn't be properly comprehended and implemented (ÇSGB \& ILO, 2017).

In this system, occupational safety specialists experience many challenges caused by employers, organizations, employees, law and legislation. Although, occupational safety specialists have to work independently, it is obvious that they are forced by considerable duties and responsibilities with limited authorization attributed from 6331 no. Law (ÇSGB \& ILO, 2017). In addition to that, employees don't contribute to occupational health and safety works rather they ignore (Başkan Takaoğlu, Çelenk Kaya \& Ölmezoğlu İri, 2018). When organizational problems are added to these challenges, working as an occupational safety specialist becomes harder. Leitão, Mc Carthy \& Greiner (2018) claimed that occupational safety professionals work efficiently when supportive work organization ensured. This ultimately enhances OHS performance of organization. Additionally, in order to provide supportive work organization, occupational safety professionals should be ensured right of decision making and enough degree of autonomy (Leitão, Mc Carthy \& Greiner, 2018). It is arguable that what extent occupational safety specialists use their authority because of receiving money from employers they audit. Occupational safety specialists also see theirselves as weak to actively reduce work accidents in workplaces (Akboğa Kale et al., 2018). Also, because of recruiting occupational safety specialists with cheap salaries, Public Health and Safety Units lead OHS to away from the main purpose (Namal, Kanber \& Kavas, 2016). For all of this reasons, works of occupational safety specialists exist on paper only, not in practice efficiently (ÇSGB \& ILO, 2017). Güzey (2014) stated that occupational safety specialists are the main responsible according to prosecutors in work accidents and deaths. Orhan (2014) also claimed that occupational safety specialists face challenges of job security and they need extra job security in order to work properly.

Even though studies on the psychological conditions of the safety professionals are limited, researches showed that psychosocial working condition such as support, demands and autonomy influences practitioner more than physical risks (Garrigou and Peissel-Cottenaz, 2008; Hovden et al., 2008; Jones, 2005). In national level, some researches have conducted descriptive studies on limited occupational safety specialists with a few variables which is already being discussed (Arslan \& Ulubeyli, 2016).

Even many countries in Europe have obligation in their law to employ safety professionals, there is no consensus on the definition of safety professionals across Europe (Hale et al., 2005). Additionally, roles and tasks of safety professionals vary across the Europe (Hale \& Guldenmund, 2006). Although safety practitioner, safety manager, safety officer, safety professional, safety coordinator is used in the literature "occupational safety specialist" is used in Turkish Occupational Health and Safety Legislation (B1yıkç1, 2010). The regulation of task, authority, responsibilities and trainings of occupational safety specialists and 6331 no. Occupational Health and Safety Law were enacted in the near past (2012). Besides, the challenges of occupational safety specialists may vary culture to culture. Although challenges and constraints of safety professionals was investigated qualitatively by Dawson, Poynter \& Stevens (1984), for this legislative and cultural reasons stated above, the scale of challenges of occupational safety specialists that is suitable for Turkish Occupational Health and Safety Legislation and Turkish culture was needed to be developed. Even though Başkan Takaoğlu, Çelenk kaya \& Ölmezoğlu İri (2018) examined the challenges of occupational safety specialists qualitatively for Turkish sample, they have just listed the challenges of occupational safety specialist. In this study, researchers was aimed to develop psychometrically reliable and valid challenges of occupational safety specialists' scale for Turkish sample.

\section{Object}

Occupational safety specialists are expected as an actor of sector to guide in ensuring safety of employees, organization and workplace and to audit practices of OHS legislation (Akboğa Kale et al., 2018). Investigating challenges of occupational safety specialists and its consequences, antecedents and related variables facilitate to find way to handle with this challenges. This enhances work conditions of occupational safety specialists and in turn, health and safety performance of organizations. This scale will provide opportunity researchers to associate organizational challenges and sub-dimensions of challenges of occupational safety specialists with other variables quantitatively.

\section{Methodology}

\section{Sample}

Data have been collected from occupational safety specialists who work in private sector including consultants. Public sector occupational safety specialists excluded from this research since the obligation of 
employing occupational safety specialist in public sector has been suspended to 2020. 332 occupational safety specialists participated to this study by using snowball sampling method. The mean age of the participants was 35.6 years in range of 21 years and 69 years. Participants consists of 72 A class $(21.7 \%), 149$ B class $(44.9 \%)$ and $111 \mathrm{C}$ class $(33.4 \%)$ occupational Safety Specialist over 20 years 209 males (63\%) and 123 females (37\%). 202 of participants employed by Public Health and Safety Unit (60.8\%), 122 participant working subject to an employer in company $(33.7 \%)$ and 18 participants work as individual consultant (5.4\%).

\section{Instruments}

\section{Demographic Information Form}

Demographic variables consist of gender, age, education status, service type, graduation field, specialization class, tenure working as an occupational safety specialists and whole working life, number of workplace, danger classes, weekly average working hours, and total employee number.

\section{Challenges of Occupational Safety Specialists Scale}

Challenges of occupational safety specialists scale is consist of 2 parts as main challenges and organizational challenges with 34 items.

\section{Psychological Safety Scale}

Psychological safety perception of occupational safety specialists was measured with seven-item scale which has been developed by Edmondson (1999). Following sentences would be given as examples of this scale; "Members of this organization are able to bring up problems and tough issues", "No one in this organization would deliberately act in a way that undermines my efforts". Yener (2015) adapted psychological safety scale into Turkish sample by conducting psychometric analysis. Adapted psychological safety scale have two sub - dimension as tolerance which are reversed items of 1,3 and 5 and initiative which are items of 2, 4, 6 and 7.

\section{Procedure}

1 open ended question related to challenges they confronted was sent in the online system to 5 occupational safety specialists to be responded. Challenges of occupational safety specialists were listed in light of responses of occupational safety specialists and related literature. Expert ideas was taken on theoretical suitability and comprehensibility of the items. At the last stage, scale was sent to one occupational safety specialists to get general information about items and 38 items was prepared for implementation.

Anonymous survey link was sent to occupational safety specialists via e - mail in the researchers' contact list and they have been asked to send the survey link to their contact / colleagues / friends to fulfill. Also, survey link shared in social media platforms of occupational safety specialists. Of 443 responses, 111 responses were disregarded because of the missing data and remaining 332 responses data was used for this study. Thus, $74 \%$ of response was reached rate was reached in a period of 2 weeks. Participants were asked to rate items on 6 point Likert-type $(1-$ totally disagree and 6 - totally agree $)$ scale.

\section{Results and Discussion}

\section{Content Validity}

5 occupational safety specialists was requested to respond 1 open ended question related to challenges they confronted. They are asked 'what challenges do you confront as an occupational safety specialists' in the online system. Responses were analyzed within the related literature. In the first phase, 44 items (34 items for main challenges part and 10 items for organizational challenges part) wereprepared according to responses. Then, this 44 items were sent to 3 professors in the area of law, psychology and engineering. After they reviewed theoretical suitability of items, 4 items were eliminated from main challenges part and 2 items were eliminated from organizational challenges part. Referees asked researchers to eliminate these 6 items because they thought that this 6 items wasn't measuring challenges of occupational safety specialists. The last version of scale was reviewed by a linguistic scientist in Sakarya University. After expert ideas was taken, researchers decided to add 'workplace(s) I service' phrase to employer and employee related items in order to provide precision to consultants about which employer and employee they consider while rating. Ultimately, scale was sent to one occupational safety specialist to get general information about items. As a result, 30 items of main challenges and 8 items of organizational challenges were involved into analyses.

\section{Factor Construct of the Main Challenges Scale}

Factorability of 30 items of main challenges scale was tested. The Barlet Sphericity value of main challenges scale was significant $(\mathrm{p}=.00<.05)$ and $\mathrm{KMO}$ value was .94 which was very high. Direct oblimin rotation method was used for factor analysis of main challenges scale. The result of the rotation could be seen in the Table 1. 5 eigenvalue of factors recorded as above 1 . Researchers has confronted that one sub - dimension which contains items of 23, 24, 25, 26, 27 and 28 has 2 two sub dimensions (items of 23, 24, 25 and 26, 27, 28) according to results of maximum likelihood factor analysis of dimensions. Therefore, fixed number of factor selected as 6. As a result of this, the items of 26,27 and 28 constituted a new factor. Even initial eigenvalue of sixth factor was 9.18, this factor has involved to the variance. This result was supported by results of structural equation modelling and this allocation complies with theoretical base of this research. Maximum Likelihood factor analysis was conducted with direct oblimin rotation. Initial eigenvalue results showed that first factor explained $46.3 \%$, second factor explained $7.94 \%$, third factor explained $4.70 \%$, fourth factor explained $4.23 \%$ and fifth factor explained $4.03 \%$, sixth factor explained $3.28 \%$ of the variance. All factor loadings met the minimum criteria except 2 items that factor loadings of them under .30 so 2 items were eliminated. Total 6 factors explained $70.57 \%$ of the variance. 
Table 1: The Results of Direct Oblimin Factor Rotation of Main Challenges Scale

\begin{tabular}{|c|c|c|c|c|c|c|c|c|}
\hline \multirow{2}{*}{ Items } & \multicolumn{5}{|c|}{ Factor } & \multicolumn{2}{|r|}{$\%$ of } & \multirow{2}{*}{$\begin{array}{c}\text { Cumulative } \\
\%\end{array}$} \\
\hline & 1 & 2 & 3 & 4 & 5 & 6 & Variance & \\
\hline Challenges 24 & 1.06 & & & & & & 46.383 & 46.383 \\
\hline Challenges 23 & .62 & & & & & & 7.949 & 54.332 \\
\hline Challenges 25 & .56 & & & & & & 4.708 & 59.039 \\
\hline Challenges 10 & & .88 & & & & & 4.223 & 63.262 \\
\hline Challenges 4 & & .71 & & & & & 4.033 & 67.295 \\
\hline Challenges 15 & & .70 & & & & & 3.28 & 70.575 \\
\hline Challenges 9 & & .70 & & & & & & \\
\hline Challenges 12 & & .69 & & & & & & \\
\hline Challenges5 & & .67 & & & & & & \\
\hline Challenges8 & & .56 & & & & & & \\
\hline Challenges 14 & & .48 & & & & & & \\
\hline Challenges 13 & & .48 & & & & & & \\
\hline Challenges6 6 & & .45 & & & & & & \\
\hline Challenges 22 & & .39 & & & & & & \\
\hline Challenges 11 & & .35 & & & & & & \\
\hline Challenges7 & & .33 & & & & & & \\
\hline Challenges 17 & & & .93 & & & & & \\
\hline Challenges 16 & & & .76 & & & & & \\
\hline Challenges 19 & & & .48 & & & & & \\
\hline Challenges 27 & & & & .84 & & & & \\
\hline Challenges 28 & & & & .76 & & & & \\
\hline Challenges 26 & & & & .41 & & & & \\
\hline Challenges 21 & & & & & .88 & & & \\
\hline Challenges 20 & & & & & .77 & & & \\
\hline Challenges 18 & & & & & .38 & & & \\
\hline Challenges2 & & & & & & .82 & & \\
\hline Challenges1 & & & & & & .71 & & \\
\hline Challenges 3 & & & & & & .38 & & \\
\hline
\end{tabular}

Maximum likelihood factor analysis with direct oblimin rotation was also conducted to all sub - dimensions of main challenges scale. Explained variances of each factors could be seen in the Table 2.

Table 2: Maximum Likelihood Factor Analysis of Dimensions of Main Challenges Scale

\begin{tabular}{|c|c|c|c|c|c|c|c|c|}
\hline Items & $\begin{array}{l}\text { Factor } 6 \\
\text { Loadings }\end{array}$ & $\begin{array}{c}\% \text { of } \\
\text { Variance }\end{array}$ & Items & $\begin{array}{c}\text { Factor } 2 \\
\text { Loadings }\end{array}$ & $\begin{array}{c}\% \text { of } \\
\text { Variance }\end{array}$ & Items & $\begin{array}{l}\text { Factor } 3 \\
\text { Loadings }\end{array}$ & $\begin{array}{c}\% \text { of } \\
\text { Variance }\end{array}$ \\
\hline Challenges1 & .850 & 75.272 & Challenges4 & .787 & 59.784 & Challenges 16 & .875 & 80.743 \\
\hline Challenges2 & .835 & & Challenges5 & .684 & & Challenges 17 & .920 & \\
\hline \multirow[t]{11}{*}{ Challenges3 } & .697 & & Challenges6 & .499 & & Challenges 19 & .738 & \\
\hline & & & Challenges 7 & .482 & & & & \\
\hline & & & Challenges8 & .728 & & & & \\
\hline & & & Challenges9 & .733 & & & & \\
\hline & & & Challenges 10 & .812 & & & & \\
\hline & & & Challenges 11 & .703 & & & & \\
\hline & & & Challenges 12 & .879 & & & & \\
\hline & & & Challenges 13 & .856 & & & & \\
\hline & & & Challenges 14 & .830 & & & & \\
\hline & & & Challenges 15 & .867 & & & & \\
\hline & & & Challenges 22 & .791 & & & & \\
\hline Items & $\begin{array}{l}\text { Factor } 5 \\
\text { Loadings }\end{array}$ & $\begin{array}{c}\% \text { of } \\
\text { Variance }\end{array}$ & Items & $\begin{array}{l}\text { Factor } 1 \\
\text { Loadings }\end{array}$ & $\begin{array}{c}\% \text { of } \\
\text { Variance }\end{array}$ & Items & $\begin{array}{l}\text { Factor } 4 \\
\text { Loadings }\end{array}$ & $\begin{array}{c}\% \text { of } \\
\text { Variance }\end{array}$ \\
\hline Challenges18 & .942 & 79.041 & Challenges 24 & .973 & 70,737 & Challenges27 & .844 & 67.116 \\
\hline Challenges 20 & .820 & & Challenges 23 & .650 & & Challenges 28 & .777 & \\
\hline Challenges 21 & .727 & & Challenges 25 & .643 & & Challenges 26 & .525 & \\
\hline
\end{tabular}

Factor 1, which is legislative challenges, covers the complexity and hardship in following of legislation to implement duties that comes from legislation. All parties agree with that present OHS legislation couldn't properly comprehended and implemented (ÇSGB \& ILO, 2017). Factor 2, which is insufficient awareness of employer, is related to inhibiting and improper approach of employers to occupational health and safety implementations. Audits and workplace surveillance should be conducted in basis of objectiveness and away from financial concerns (Bıyıkç1, 2010). Intervention of employer is the considerable challenge that occupational safety specialists face. To be paid salary directly from employer is the one of the threats for job independency of occupational safety specialists (Arslan ve Ulubeyli, 2016). Factor 3, which is unwillingness of employees to participation, involves the unwillingness of employees to OHS related activities. Factor 4, which is law based challenges, includes the challenges caused by 6331 no. OHS Law that specifies the responsibilities, obligations and authority of parties and have broader attributions and references on occupational health and safety implementations than legislation. Many articles in 6331 no. OHS law are contentious (Emiroğlu ve Koşar, 2012). According to Taşkıran (2016), one of the main reason to arbitrary attitude of employer is that occupational safety 
specialists are exposed intense responsibilities. Factor 5, which is ignorance of employees, covers the improper approach of employees to OHS related rules, instructions and hazards at workplaces. Employees don't comply with rules and instructions, ignores occupational health and safety related events (Başkan Takaoğlu, Çelenk kaya \& Ölmezoğlu İri, 2018). Factor 6, providing lack of resources, involves the approach of employers on providing lack of resources to employees regarding to their works (equipments, devices and tools) and OHS related personal protective equipments. Occupational health and safety investments regarded as an expense by the employers. Thus, employers doesn't willing to create a budget for occupational health and safety (Ak1n, 2012). Original form of scales are Turkish as could be seen in the Appendix 1. As a results of Spearman correlation coefficients, there was positive and significant $(\mathrm{p}<.01)$ correlations between all dimensions of main challenges scale.

\section{Confirmatory Factor Analysis Results of Main Challenges Scale}

In order to test validity of 6 factor of the main challenges scale, confirmatory factor analysis was employed. Factor loadings on 6 factor vary in range of .33 and 1.06. Participants were asked to rate items on 6 point Likerttype (1 - totally disagree and 6 - totally agree) scale. Chi square and model fit indexes are utilized in confirmatory factor analysis. To test model fit of scale, either a few of model fit indices or whole of model fit indexes could be used (Schumacker, 2006). There is no consensus in the literature on what model fit indices have to be used (İlhan ve Çetin, 2014).

Reported indexes varies according to consideration of researcher (Gerbing \& Anderson, 1992). Confirmatory factor analysis showed that model fit of main challenges scale was in acceptable ranges. $(\chi 2=934,707 \mathrm{DF}=333$, $\chi 2 / \mathrm{DF}=2.8, \mathrm{p}<.001, \mathrm{CFI}=.904, \mathrm{RMSEA}=.074, \mathrm{IFI}:$ .904, PNFI: .756, PGFI: .674). Model of confirmatory factor analysis of the main challenges scale was shown in Figure 1.

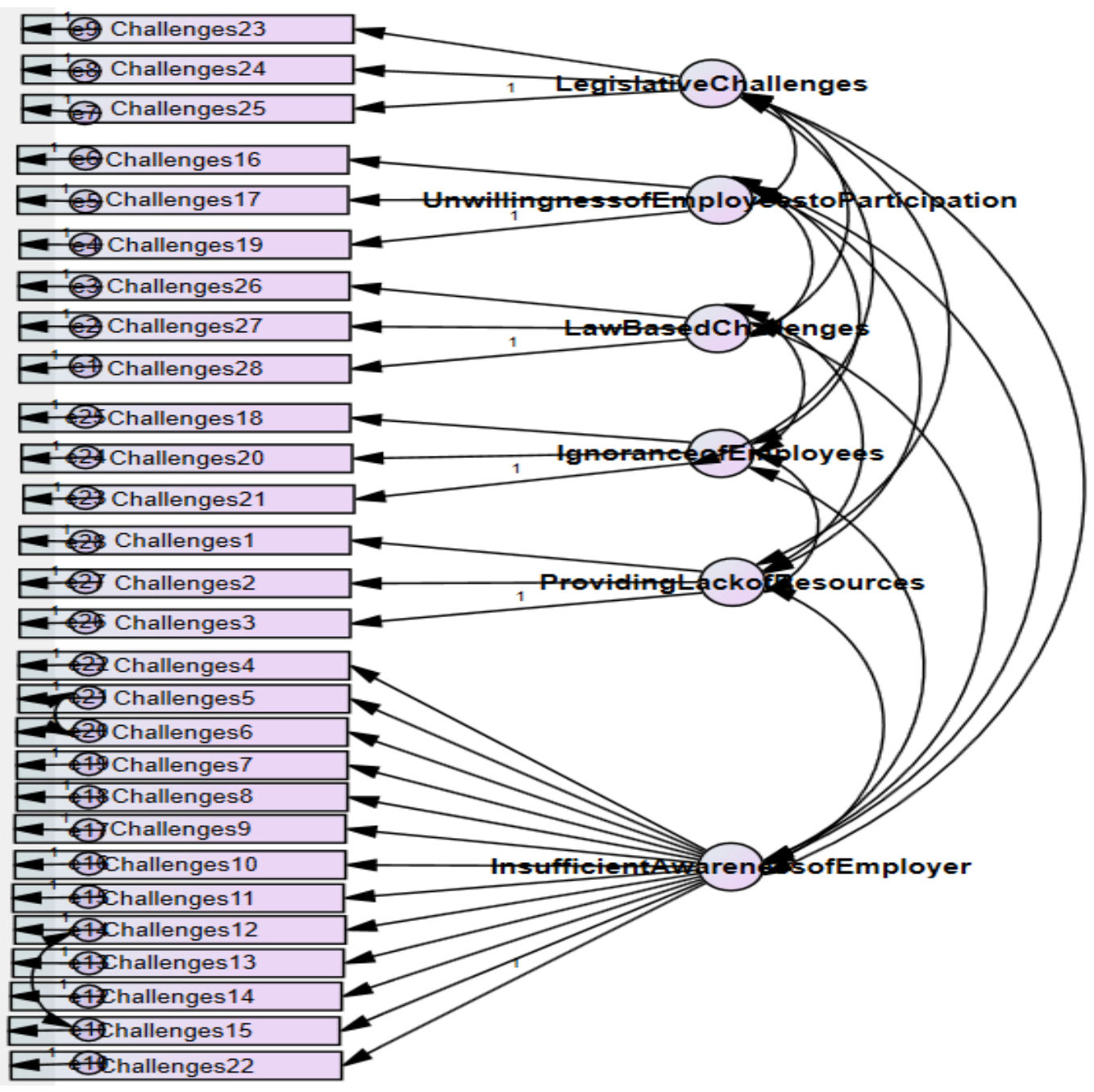

Figure 1. Model of Confirmatory Factor Analysis of Main Challenges Scale 
Reliability Analysis of the Main Challenges Scale

Cronbach's alpha internal consistency coefficient of main challenges scale was observed as .954. Besides,
Cronbach's Alpha coefficients of sub-dimensions of main challenges scale could be seen in the Table 3 .

Table 3: Reliability Analysis of the Main Challenges Scale

\begin{tabular}{|c|c|c|c|c|c|}
\hline & Mean & $\begin{array}{c}\text { Std. } \\
\text { Deviation }\end{array}$ & $\begin{array}{c}\text { Corrected } \\
\text { Item-Total } \\
\text { Correlation }\end{array}$ & $\begin{array}{c}\text { Cronbach's } \\
\text { Alpha } \\
\text { if Item } \\
\text { Deleted }\end{array}$ & $\begin{array}{c}\text { Internal } \\
\text { Consistency } \\
\text { Coefficient }\end{array}$ \\
\hline \multicolumn{6}{|c|}{ Legislative Challenges } \\
\hline Challenges 24 & 3.21 & 1.47 & .74 & .589 & \\
\hline Challenges 23 & 3.24 & 1.56 & .57 & .769 & \\
\hline Challenges 25 & 3.58 & 1.56 & .57 & .774 & \\
\hline Total & & & & & .789 \\
\hline \multicolumn{6}{|c|}{ Insufficient awareness of employer } \\
\hline Challenges10 & 4.38 & 1.50 & .79 & .934 & \\
\hline Challenges 4 & 4.32 & 1.59 & .77 & .935 & \\
\hline Challenges15 & 4.00 & 1.49 & .82 & .934 & \\
\hline Challenges9 & 4.47 & 1.51 & .71 & .937 & \\
\hline Challenges12 & 4.07 & 1.56 & .83 & .933 & \\
\hline Challenges5 & 4.12 & 1.64 & .69 & .937 & \\
\hline Challenges8 & 3.69 & 1.64 & .70 & .937 & \\
\hline Challenges 14 & 3.87 & 1.53 & .78 & .934 & \\
\hline Challenges 13 & 3.79 & 1.50 & .81 & .934 & \\
\hline Challenges6 & 4.40 & 1.54 & .51 & .943 & \\
\hline Challenges 22 & 3.92 & 1.55 & .63 & .935 & \\
\hline Challenges 11 & 3.67 & 1.51 & .67 & .938 & \\
\hline Challenges 7 & 3.35 & 1.60 & .49 & .944 & \\
\hline Total & & & & & .941 \\
\hline \multicolumn{6}{|c|}{$\begin{array}{l}\text { Unwillingness of Employees to } \\
\text { Participation }\end{array}$} \\
\hline $\begin{array}{l}\text { Challenges17 } \\
\text { Chen }\end{array}$ & 3.35 & 1.55 & .81 & .784 & \\
\hline Challenges 16 & 3.42 & 1.56 & .79 & .809 & \\
\hline Challenges 19 & 3.88 & 1.51 & .69 & .892 & \\
\hline Total & & & & & .881 \\
\hline \multicolumn{6}{|c|}{ Law Based Challenges } \\
\hline Challenges 27 & 4.88 & 1.26 & .65 & .580 & \\
\hline Challenges 28 & 4.39 & 1.40 & .61 & .611 & \\
\hline Challenges 26 & 4.86 & 1.44 & .46 & .753 & \\
\hline Total & & & & & .747 \\
\hline \multicolumn{6}{|c|}{ Ignorance of Employees } \\
\hline Challenges21 & 3.79 & 1.48 & .81 & .741 & \\
\hline Challenges 20 & 3.54 & 1.54 & .75 & .810 & \\
\hline Challenges 18 & 3.65 & 1.32 & .67 & .871 & \\
\hline Total & & & & & .866 \\
\hline \multicolumn{6}{|c|}{ Providing Lack of Resources } \\
\hline Challenges2 & 3.12 & 1.43 & .73 & .735 & \\
\hline Challenges1 & 2.94 & 1.52 & .72 & .744 & \\
\hline Challenges 3 & 3.32 & 1.48 & .63 & .829 & \\
\hline Total & & & & & .835 \\
\hline \multicolumn{5}{|c|}{ Internal Consistency Coefficient of the Main Challenges Scale } & .954 \\
\hline
\end{tabular}

\section{Factor Construct of Organizational Challenges Scale}

8 items of the organizational challenges scale were involved into analyses. Organizational challenges part was initially thought as integrated to main challenges part but as a result of structural equation modelling, organizational challenges scale was divided from main challenges scale. Organizational challenges part was conducted with notification for participants that they were expected to consider their organization instead of organization they service because participants who are working as a consultants may be confused in terms of whether they consider their consulting organization or organization they service. Scale was implemented to 314 occupational safety specialists. All factor loadings met the minimum criteria except 2 items that factor loadings under .30 so 2 items were eliminated. Thus, factorability of 6 items of organizational challenges scale was examined. The Barlet Sphericity value of organizational challenges scale was significant $(\mathrm{p}=.00<.05)$ and KMO value was .846 which was very high. Direct oblimin rotation method was used for factor analysis of organizational challenges scale. Only one eigenvalue of factor recorded as above 1 in the Total Explain table. Initial eigenvalue results showed that first factor explained $52.9 \%$ of the variance. These indications supported that the items were loaded to one factor. The results of direct oblimin factor rotation of organizational challenges scale was shown in the Table 4. 
Table 4: The Results of Direct Oblimin Factor Rotation of Organizational Challenges Scale

\begin{tabular}{|c|c|c|c|}
\hline Items & $\begin{array}{c}\text { Factor } \\
\text { Loadings }\end{array}$ & $\%$ of Variance & $\begin{array}{c}\text { Cumulative } \\
\%\end{array}$ \\
\hline \multirow{6}{*}{$\begin{array}{l}\text { 3. I am not appreciated after achieved successfull work. } \\
\text { 4. My authority is limited as an occupational safety specialist. } \\
\text { 5. Assigned tasks and responsibilities are too much to me as an } \\
\text { occupational safety specialist. } \\
\text { 1. Carrier opportunity is limited in my position. } \\
\text { 2. My salary is inadequate against risks that I am exposed to. } \\
6 \text {. I will be one of the primary charged people in case of occupational } \\
\text { accident. }\end{array}$} & .716 & \multirow[t]{6}{*}{52.967} & \multirow[t]{6}{*}{52.967} \\
\hline & .712 & & \\
\hline & .706 & & \\
\hline & .680 & & \\
\hline & .633 & & \\
\hline & .503 & & \\
\hline
\end{tabular}

\section{Reliability Analysis of Organizational Challenges \\ Scale}

Organizational challenges scale has a .818 Cronbach's alpha value, which represents high level of internal consistency. Reliability analysis of organizational challenges scale could be seen in the Table 5 .

Table 5: Reliability Analysis of Organizational Challenges Scale

\begin{tabular}{|c|c|c|c|c|}
\hline Items & $\begin{array}{l}\text { Mea } \\
\mathrm{n}\end{array}$ & $\begin{array}{l}\text { Std. } \\
\text { Deviation }\end{array}$ & $\begin{array}{c}\text { Corrected } \\
\text { Item-Total } \\
\text { Correlation }\end{array}$ & $\begin{array}{c}\text { Cronbach's } \\
\text { Alpha if Item } \\
\text { Deleted }\end{array}$ \\
\hline Career opportunity is limited in my position. & 4.45 & 1.58 & .59 & .787 \\
\hline My salary is inadequate against risks that I am exposed to. & 5.35 & 1.21 & .56 & .794 \\
\hline I am not appreciated after achieved successfull work. & 4.19 & 1.57 & .64 & .775 \\
\hline My authority is limited as an Occupational Safety Specialist & 4.75 & 1.51 & .63 & .778 \\
\hline $\begin{array}{l}\text { Assigned tasks and responsibilities are too much to me as an Occupational Safety } \\
\text { Specialist }\end{array}$ & 5.10 & 1.19 & .62 & .783 \\
\hline I will be one of the primary charged people in case of occupational accident. & 5.15 & 1.34 & .45 & .815 \\
\hline Internal Consistency Coefficient of the Organizational Challenges of Scale & & & & .818 \\
\hline
\end{tabular}

\section{Convergent Validity Analysis}

In this study psychological safety scale was used to test the convergent validity of main challenges scale and organizational challenges scale. The correlations between scales were shown in Table 6 . As could be seen in Table 6 , insufficient awareness of employer negatively correlated with tolerance $(\mathrm{r}=-.383, \mathrm{p}<.05)$ and initiative $(\mathrm{r}=-.334, \mathrm{p}<.05)$. This result showed that occupational safety specialists who confront insufficient awareness of employer challenges, feel less tolerance and less supported to take initiative in organizations. Unwillingness of employees negatively correlated with tolerance $(\mathrm{r}=-353, \mathrm{p}<.05)$ and initiative $(\mathrm{r}=-.205, \mathrm{p}<.05)$, indicated that occupational safety specialists who confront unwillingness of employees challenges, feel less tolerance and less supported to take initiative in organizations.

Table 6: The Correlations Between Sub - Dimensions of Psychological Safety, Main Challenges and Organizational Challenges

\begin{tabular}{|c|c|c|c|c|c|c|c|c|c|c|c|c|}
\hline & Spearman's rho & 1 & 2 & 3 & 4 & 5 & 6 & 7 & 8 & Tolerance & Initiative & $\begin{array}{c}\text { Total } \\
\text { Psychological } \\
\text { Safety }\end{array}$ \\
\hline 1 & $\begin{array}{l}\text { Insufficient Awareness of } \\
\text { Employer }\end{array}$ & - & $.713^{* *}$ & $.776^{* *}$ & $.728^{* *}$ & $.336^{* *}$ & $.423^{* *}$ & $.951^{* *}$ & $.549^{* *}$ & $-.383^{* *}$ & $-.334^{* *}$ & -.034 \\
\hline 2 & $\begin{array}{l}\text { Unwillingness of Employees } \\
\text { to Participation }\end{array}$ & & - & $.724^{* *}$ & $.588^{* *}$ & $.304^{* *}$ & $.300^{* *}$ & $.798^{* *}$ & $.423^{* *}$ & $-.353^{* *}$ & $-.205^{* *}$ & .077 \\
\hline 3 & Ignorance of Employees & & & - & $.662^{* *}$ & $.323^{* *}$ & $.395^{* *}$ & $.867^{* *}$ & $.456^{* *}$ & $-.319^{* *}$ & $-.280^{* *}$ & -.027 \\
\hline 4 & Providing Lack of Resources & & & & - & $.292^{* *}$ & $.326^{* *}$ & $.793^{* *}$ & $.386^{* *}$ & $-.325^{* *}$ & $-.273^{* *}$ & -.016 \\
\hline 5 & Legislative Challenges & & & & & - & $.399^{* *}$ & $.483^{* *}$ & $.234^{* *}$ & $-.234^{* *}$ & .000 & $.144^{* * *}$ \\
\hline 6 & Law Based Challenges & & & & & & - & $.529^{* *}$ & $.414^{* *}$ & $-.224^{* *}$ & -.102 & .079 \\
\hline 7 & Total Main Challenges & & & & & & & - & $.551^{* *}$ & $-.405^{* *}$ & $-.300^{* *}$ & .016 \\
\hline 8 & Organizational Challenges & & & & & & & & - & $-.387^{* *}$ & $-.298^{* *}$ & -.005 \\
\hline
\end{tabular}


Ignorance of employees negatively correlated with tolerance $(\mathrm{r}=-.353, \mathrm{p}<.05)$ and initiative $(\mathrm{r}=-.280, \mathrm{p}<$ .05 ), showed that occupational safety specialists who confront ignorance of employees challenges, feel less tolerance and less supported to take initiative in organizations. Providing lack of resources negatively correlated with tolerance $(r=-.325, \mathrm{p}<.05)$ and initiative $(\mathrm{r}=-.273, \mathrm{p}<.05)$. This result showed that occupational safety specialists who confront providing lack of resources challenges, feel less tolerance and less supported to take initiative in organizations. Legislative challenges negatively correlated with tolerance $(r=-.234$, $\mathrm{p}<.05)$ and total psychological safety $(\mathrm{r}=.144, \mathrm{p}<.05)$, showed that occupational safety specialists who confront legislative challenges, feel less tolerance and occupational safety specialists experience more legislative challenges in psychologically safer organizations. Law based challenges negatively correlated with tolerance $(\mathrm{r}=-224, \mathrm{p}<.05)$. This result revealed that occupational safety specialists who confront law based challenges, feel less tolerance in organizations. Total main challenges negatively correlated with tolerance $(r=-.405, \mathrm{p}<.05)$ and initiative $(r=-.300, \mathrm{p}<.05)$, indicated that occupational safety specialists who confront total main challenges, feel less tolerance and less supported to take initiative in organizations. Organizational challenges negatively correlated with tolerance $(\mathrm{r}=-.387, \mathrm{p}<.05)$ and initiative $(\mathrm{r}=.-298, \mathrm{p}<.05)$. This result revealed that occupational safety specialists who confront organizational challenges, feel less tolerance and less supported to take initiative in organizations. As a result, findings showed the expectancy of researchers on the relationship between main challenges, organizational challenges and psychological safety. Therefore, psychological safety

\section{References}

Akboğa Kale et al..(2018). İş güvenliği uzmanlığı sisteminin gelişimi üzerine bir alan çalışması. Ballkesir Üniversitesi Fen Bilimleri Enstitüsü Dergisi, 1 -14.

Akın, L. (2012). Sendikaların İş Sağlı̆̆ı ve Güvenliğinin Sağlanmasına Katkısı. Çalışma ve Toplum, 34, 101-123.

Arslan, V. \& Ulubeyli, S. (2016). A field research for problems of occupational safety experts. Çallşma ve Toplum, 1321-1340.

Atherley, GRC and Hale, AR. (1975). Prerequisites for a profession in occupational safety and hygiene. Annals of Occupational Hygiene, 18, 321-334.

Başkan Takaoğlu, Z, Çelenk Kaya, E \& Ölmezoğlu İri, N. (2018). The problems of occupational safety specialists. Gümüşhane University Journal of Health Sciences, 7(2), 1-9.

Biyikci, E.T. (2010). İş sağlığı ve güvenliğinin sağlanmasında iş güvenliği uzmanlı̆̆1 (Yüksek Lisans Tezi). Uludağ Üniversitesi, Bursa, Turkey.

Cattaruzza, E and Huguet, M. (1993). Training of prevention experts: summary report. Paris: International Social Security Association, Section on Education and Training in Prevention, Caisse Regionale d'Assurance Maladie d'Ile de France.

ÇSGB, ILO (2017). İş Güvenliği Uzmanlarının Görev ve Sorumluluklarının Yürütülmesi ile ilgili Araştırma. Ankara, Turkey.

Dawson S., Poynter P. \& Stevens D. (1984). Safety Specialists in Industry: Roles, Constraints and Opportunities. Journal of Occupational Behaviour, 5(4), 253- 270.

Emiroğlu, C. \& Koşar, L. (2012). İş sağlığı ve güvenliği kanunu üzerine. TTB Mesleki Sağllk ve Güvenlik Dergisi, 43, 2-15. would be taken into account in challenges researches as complimentary part.

\section{Conclusion}

In this study, researchers was aimed to develop psychometrically reliable and valid challenges of occupational safety specialists' scale for Turkish sample. Psychometric results of this scales were shown that both main challenges scale and organizational challenges scale was suitable for Turkish sample. Main challenges scale have 6 factors that measures challenges stemming from employers, employees, 6331 no. Occupational Health and Safety Law and legislation with 28 items and organizational challenges scale have 1 factor with 6 items. As a result, investigating the challenges of occupational safety specialists, as an one of the main actor in occupational health and safety area, will contribute the health and safety performance of organizations and in turn, health and safety of employees.

\section{Suggestions}

Psychometrically valid and reliable main challenges scale and organizational challenges scale for Turkish sample was developed within this study. In the following studies, researchers may investigate the challenges of the other health and safety professionals in Turkey such as occupational physicians or occupational nurses. Researchers may also integrate this scale to qualitative challenges studies and associate with other variables. This scale would be implemented to all occupational safety specialists regardless of sector, thus this may allow researchers to develop sector specific solutions for occupational safety specialists.

European Commission. (1989). Directive concerning the execution of measures to promote the improvement of the safety and health of workers at their work and other subjects (framework directive). Official Journal of EC, 12 June.

Garrigou, A., Peissel-Cottenaz, G., 2008. Reflexive approach to the activity of preventionists and their training needs: results of a French study. Safety Science, 46, 1271-1288.

Gerbing, D.W. \& Anderson, J.C. (1992). Monte Carlo evaluations of goodness of fit indices for structural equation models. Sociological Methods and Research, 21(2), 132-160.

Güzey, Z. (2014), 6331 sayılı yasa çerçevesinde iş güvenliği uzmanlarının sorunları, Mühendis ve Makina Dergisi, 55(155).

Hale, A.R, Bianchi G., Dudka, G., Hameister, W., Jones, R., Perttula, P. \& Ytrehus I. (2005). Surveying the role of safety professionals: objectives, methods \& early results. Safety Science Monitor, 9 (1).

Hale, A.R, Guldenmund F.G. (2006). Role and tasks of safety professionals: some results from an international survey. Safety science group.

Hale, A.R., Piney, M and Alesbury, R. (1986). The development of occupational hygiene and the training of health and safety professionals. Annals of Occupational Hygiene, 30(1), 1-18.

Hovden, J., Lie, T., Karlsen, J.E., Alteren, B., (2008). The safety representative under pressure. A study of occupational health and safety management in the Norwegian oil and gas industry. Safety Science, 46, 493-509. 
INSHPO (International Network of Safety and Health Practitioner Organisations). (2017). The Occupational Health and Safety Professional Capability Framework: A global framework for practice. International Network of Safety and Health Practitioner Organisations (INSHPO). Park Ridge, IL, USA.

Ilhan, M. \& Çetin, B. (2014). Lisrel ve Amos programları kullanılarak gerçekleştirilen yapısal eşitlik modeli (yem) analizlerine iliş̧in sonuçların karșılaştırılması. Eğitimde ve Psikolojide Ölçme ve Değerlendirme Dergisi, 5(2), $26-42$.

Jones, R., (2005). In: IOSH (Ed.), What Practitioners Do - A Survey of UK Registered Safety Practitioners to Determine Their Roles and Tasks. IOSH, Leicestershire.

Leitão, S, Mc carthy, V.J.C. \& Greiner, B.A. (2018). Health and safety practitioners health and wellbeing - the link with safety climate and job demand-control-support. Accident Analysis and Prevention, 119, 131-137.

\section{Appendix 1. İş Güvenliği Uzmanlarının Sorunları Ölçeği (Turkish)}

Aşağıda yeralan anket özel sektörde çalışan İş Güvenliği Uzmanlarının iş hayatında karşılaştıkları durumların araştırılması amacıyla hazırlanmıştır. Anket 36 sorudan oluşmaktadır. Lütfen ankette belirtilen durumlarla ne sıklıkta karşılaştığınızı; 1 - Kesinlikle Katılmıyorum, 2- Katılmıyorum, 3 -Kısmen Katılmıyorum, 4 - Kısmen Katılıyorum, 5 - Katılıyorum, 6 - Kesinlikle Katılıyorum şeklinde işaretleyiniz

\begin{tabular}{|c|c|c|c|c|c|c|c|}
\hline \multicolumn{2}{|r|}{ Lütfen işyerinizde aşağıda verilen önermeler ile karşılaștığınızı düşünüyorsanız; } & 1 & 2 & 3 & 4 & 5 & 6 \\
\hline 1 & $\begin{array}{l}\text { Hizmet verdiğim işyer(ler)inde işveren, çalışanları gerekli makine, ekipman, cihaz, araç ve gereçleri } \\
\text { sağlamadan çalıştırır. }\end{array}$ & ( ) & ( ) & $($ ) & $($ ) & ( ) & ( ) \\
\hline 2 & $\begin{array}{l}\text { Hizmet verdiğim işyer(ler)inde işveren, çalışanları uygun Kişisel Koruyucu Donanımları sağlamadan } \\
\text { çalıştırır. }\end{array}$ & ( ) & ( ) & $($ ) & ( ) & ( ) & ( ) \\
\hline 3 & Hizmet verdiğim işyer(ler)inde işveren, İSG saha gözlem ve denetim raporlarımı dikkate almaz. & $($ ( ) & $($ ) & () & $($ ( ) & $($ ( ) & () \\
\hline 4 & $\begin{array}{l}\text { Hizmet verdiğim işyer(ler)inde işveren, nitelikli İSG eğitimleri sunmak yerine sadece yasal } \\
\text { yükümlülüğunü yerine getirme eğilimindedir. }\end{array}$ & ( ) & $($ ) & $($ ) & ( ) & ( ) & ( ) \\
\hline 5 & İşveren, maaşımı ödediği için kendisine aykırı hareket etmemem gerektiğini hissettirir. & ( ) & ( ) & ( ) & ( ) & ( ) & ( ) \\
\hline 6 & Hizmet verdiğim işyer(ler)inde, İSG eğitimleri işverenin istediği yer ve zamana göre planlanır. & ( ) & ( ) & ( ) & ( ) & ( ) & ( ) \\
\hline 7 & $\begin{array}{l}\text { Hizmet verdiğim işyer(ler)inde işveren, onaylı deftere istemediği tedbir ve önerileri yazmama müsaade } \\
\text { etmez. }\end{array}$ & ( ) & ( ) & ( ) & ( ) & ( ) & ( ) \\
\hline 8 & Hizmet verdiğim işyer(ler)inde işveren, İSG yükümlülüklerinin farkında değildir. & ( ) & $($ ) & ( ) & ( ) & ( ) & $($ ) \\
\hline 9 & $\begin{array}{l}\text { Hizmet verdiğim işyer(ler)inde işveren, Kişisel Koruyucu Donanımları tedarik ederken ergonomikliği ve } \\
\text { koruyucu özelliklerinden önce maliyetini düşünür. }\end{array}$ & $($ ) & $($ ) & $($ ) & $($ ) & ( ) & ( ) \\
\hline 10 & $\begin{array}{l}\text { Hizmet verdiğim işyer(ler)inde işveren, İSG kapsamında hazırladığım formları, talimatları, prosedürleri } \\
\text { ve planları yalnızca yasal yükümlülügün yerine getirilmesi amacıyla kullanır. }\end{array}$ & ( ) & ( ) & $($ ) & $($ ) & ( ) & ( ) \\
\hline 11 & $\begin{array}{l}\text { Hizmet verdiğim işyer(ler)inde işveren, çalışanların görev dağılımını yaparken sağlık ve güvenlik } \\
\text { yönünden işe uygunluklarını gözardı eder. }\end{array}$ & ( ) & ( ) & ( ) & ( ) & ( ) & ( ) \\
\hline 12 & Hizmet verdiğim işyer(ler)inde işveren, İSG yatırımlarını gereksiz maliyet olarak görür. & ( ) & ( ) & ( ) & ( ) & ( ) & ( ) \\
\hline 13 & Hizmet verdiğim işyer(ler)inde işveren, risk değerlendirme sonuçlarına göre etkin önlemler almaz. & $(\mathrm{)})$ & () & $(\mathrm{)})$ & () & $(\mathrm{)})$ & $(\mathrm{)})$ \\
\hline 14 & Hizmet verdiğim işyer(ler)inde işveren, İSG tedbirlerine uyulup uyulmadığını takip etmez. & ( ) & ( ) & ( ) & ( ) & ( ) & ( ) \\
\hline 15 & Hizmet verdiğim işyer(ler)inde işveren, İSG eğitimlerini zaman kaybı olarak değerlendirir. & ( ) & ( ) & ( ) & ( ) & ( ) & ( ) \\
\hline 16 & Hizmet verdiğim işyer(ler)inde çalışanlar, İSG eğitimlerine gerekli katılımı sağlamazlar. & () & ( ) & () & () & () & () \\
\hline 17 & Hizmet verdiğim işyer(ler)inde çalışanlar, Acil Durum Tatbikatlarına gerekli katılımı sağlamazlar. & $(\mathrm{)}$ & ( ) & ( ) & ( ) & ( ) & ( ) \\
\hline 18 & Hizmet verdiğim işyer(ler)inde çalışanlar, iş güvenliği emir ve talimatlarına uymazlar. & ( ) & ( ) & ( ) & ( ) & ( ) & ( ) \\
\hline 19 & Hizmet verdiğim işyer(ler)inde çalışanlar, İSG eğitimlerini zaman kaybı olarak değerlendirirler. & () & $($ ) & ( ) & $($ ) & () & () \\
\hline 20 & $\begin{array}{l}\text { Hizmet verdiğim işyer(ler)inde çalışanlar, tehlike ile karşılaştıklarında işverenden önlem alınmasını } \\
\text { istemezler. }\end{array}$ & ( ) & ( ) & ( ) & ) & ( ) & ) \\
\hline 21 & Hizmet verdiğim işyer(ler)inde çalışanlar, karşılaştıkları tehlikeli durum ve olayları önemsemezler. & ( ) & ( ) & ( ) & ( ) & ( ) & ( ) \\
\hline 22 & Hizmet verdiğim işyer(ler)inde İSG'ye ilişkin tedbirler denetim dönemleri ile sınırlı kalır. & ( ) & ( ) & ( ) & ( ) & ( ) & ( ) \\
\hline 23 & İSG mevzuat güncellemelerinin takibi zordur. & ( ) & ( ) & ( ) & ( ) & ( ) & ( ) \\
\hline 24 & İSG mevzuatının anlaşılması zordur. & ( ) & ( ) & ( ) & ( ) & ( ) & ( ) \\
\hline 25 & İSG mevzuatı fazla ayrıntılı olmasından dolayı tümüyle uygulanması zordur. & ( ) & ( ) & ( ) & ( ) & ( ) & $($ ( ) \\
\hline 26 & İSG kanunu yasanın uygulanmasını büyük ölçüde İş Güvenliği Uzmanına yüklemektedir. & () & ( ) & ( ) & ( ) & () & ( ) \\
\hline 27 & İSG Kanunu çalışanların işyerinde psikolojik iyilik hallerinin sağlanması açısından yetersizdir. & () & $($ ) & () & $($ ) & () & () \\
\hline 28 & İSG Kanunun önemli ölçüde teknik önlemler üzerinde durması kazaların önlenmesinde yetersizdir. & ( ) & ( ) & ( ) & $($ ) & ( ) & ( ) \\
\hline \multicolumn{8}{|c|}{$\begin{array}{l}\text { Lütfen aşağıgdaki durumları hizmet verdiğiniz işyerlerine göre değil, bağlı olduğunuz organizasyona göre değerlendiriniz. (OSGB'de çalışıorsanız } \\
\text { OSGB'nizi değerlendiriniz. Firmaya bağlı olarak çalışıorsanız bağlı olduğunuz firmayı değerlendiriniz). Bireysel iş güvenliği danışmanlığı } \\
\text { yapıyorsanız lütfen bu kısmı boş bırakınız. }\end{array}$} \\
\hline 1 & Bulunduğum pozisyonda kariyer imkanı kısitlıdır. & $(\mathrm{)})$ & ( ) & ( ) & $(\mathrm{C})$ & $(\mathrm{)}$ & $(\mathrm{)})$ \\
\hline 2 & Aldığım riske göre maaşım yetersizdir. & ( ) & ( ) & ( ) & ( ) & ( ) & ( ) \\
\hline 3 & İşimde elde ettiğgim başarıların sonunda takdir edilmem. & ( ) & ( ) & ( ) & ( ) & ( ) & ( ) \\
\hline 4 & İș Güvenliği Uzmanı olarak yetkilerim sınırlıdır. & () & ( ) & ( ) & ( ) & ( ) & () \\
\hline 5 & İș Güvenliği Uzmanı olarak üzerime yüklenen görev ve sorumluluklar fazladır. & ( ) & ( ) & ( ) & ( ) & ( ) & ( ) \\
\hline 6 & İş kazası meydana geldiğinde asli kusurlulardan biri olarak görüleceğimi bilirim. & ( ) & ( ) & ( ) & ( ) & ( ) & ( ) \\
\hline
\end{tabular}

Namal, B., Kanber, H. \& Kavas, M.V. (2016). The ethical problems that occupational safety specialists face because of getting their wages from the institutions they inspect. Turkish Journal of Bioethics, 3(3), 146-164.

Orhan, S. (2014). The problem of job security for occupational safety specialists. HAK-IŞ Uluslararası Emek ve Toplum Dergisi, 3(6), 70-89.

Schumacker, R. E. (2006). Conducting specification searches with Amos. Structural equation modeling: A Multidisciplinary Journal, 13 (1), 118- 129.

Taşkiran, G. (2016). Unsecured occupational safety specialists, marketable occupational safety: A Field Research. Çalışma ve Toplum, 4, 1747-1768.

Yener (2015). Psikolojik rahatlık ölçeğinin türkçe formunun geçerlilik ve güvenirlik çalışması, Ordu Üniversitesi Sosyal Bilimler Araştırmaları Dergisi, 280 - 305. 